\title{
The Effect of Motivation on Students Studying in Sports Departments
}

\author{
Kübra Özdemir ${ }^{1}$ \\ ${ }^{1}$ Physical Education and Sports, Kazım Karabekir Faculty of Education, Atatürk University, Erzurum, Turkey \\ Correspondence: Kübra Özdemir, Physical Education and Sports, Kazım Karabekir Faculty of Education, Atatürk \\ University, Erzurum, Turkey. E-mail: kubra.ozdemir@atauni.edu.tr
}

Received: July 15, 2020

doi:10.5539/ies.v14n3p72
Accepted: October 21, $2020 \quad$ Online Published: February 20, 2021

URL: https://doi.org/10.5539/ies.v14n3p72

\begin{abstract}
This study aims to analyze participation motivation of the students studying in the department of Physical education and Sports teaching. The study population consists of 160 students from the Department of Physical Education and Sports Teaching in Kazım Karabekir Faculty of Education at Atatürk University in the 2019-2020 academic year. The study sample is 99 students out of 160 students by choosing the random sampling method. A form consisting of two parts has been used as a data collection tool in the study. In the first part of the data collection tool, there is a personal information form, including the students' age, gender, and sports information branch. In the second part, participation motivation questionnaire has been used. Normal distribution criteria have been controlled using Kolmogorov-Smirnov and Shapiro-Wilk tests in the obtained data. Non-parametric tests have been used in the next stage's statistical analysis. While comparisons of gender and sports type have been fulfilled with the Mann Whitney-U test, the Kruskal Wallis test has been used for the age variable. Consequently, it has been observed that the most crucial reason directing students to sports is "skill development" and the least important reason is "friends". When looking at the values obtained from the Participation Motivation Questionnaire by gender, it is evident that there is no statistically significant difference according to the scores obtained by male and female students from the sub-dimensions of the scale.
\end{abstract}

Keywords: motivation, university students, performance, physical activity, sport

\section{Introduction}

Motivation is defined as an energetic behaviour directed towards a specific purpose, the sum of efforts made to mobilize various numbers of human groups towards a desired goal, or acting with personal desires and desires to achieve a specific goal of people (Knittle et al., 2018). One of the most important features of motivation is that it is individual. Human is at the center of Motivation. People are distinguished not only by their abilities but also by their motivation (Park, Lim, \& Lim, 2020). Motivation is an individual phenomenon because it varies from person to person. The diversity of people's needs is one of the main factors that determine the level of motivation (Osabiya, 2015).

\subsection{Types of Motivation}

According to the Cognitive-Appraisal Theory, motivation is divided into three types depending on the reason for its occurrence. These are Situational and Continuous Motivation, Intrinsic and Extrinsic Motivation, and lastly Integrative and Instrumental Motivation. The forces that motivate individuals from the first moment they are born to constitute intrinsic motivation (Breva, \& Galindo, 2020). The reason people turn to the targeted action is the pleasure, interest, success, satisfaction, pleasure, excitement, fun, and happiness that the action will gain from $\mathrm{him} /$ her personally (Ingledew, Markland, \& Sheppard, 2004). Contrary to the intrinsic motivation; if we consider extrinsic motivation, it is the behaviours performed in order not to feel guilty or to get any reward (Boiché \& Sarrazin, 2007). In Situational and Continuous Motivation, the type of motive emerging with the effect of the present moment is called situational motivation. These are non-continuous and temporary types of motives. For instance, the motives we experience while writing the homework that needs to be completed in a certain period of time or while studying for the exam are situational ones.

Contrary to the state motive, the type of motive that is always present in individuals and arises without any reason is the type of continuous motive and permanent (Akbaba, 2006). It was evaluated the Integrative and Instrumental Motivation, the Integrative motivation also expresses the motivation of people to learn a foreign language because they are cute towards people or countries speaking any foreign language they want to learn, and therefore their 
desire to participate in activities in language learning (Kaya, 2017) Instrumental motivation is handled together with integrative motivation. As it is understood from its name, it is a type of motivation that considers learning language as a tool rather than a goal and aims to be used as a tool rather than as a goal in advancing the set goals (Canitezer, 2014).

When the above written are analyzed, it is understood that there are many factors such as requests, needs, and emotions that affect the behavior of individuals. The first step to support learning motivation is to understand motivation. For the instructors to be effective in the classroom, they should have the knowledge of in-class strategy, and thus, the teacher can control the classroom more easily and can apply appropriate methods and techniques (Moreno, 2009).

\subsection{Factors Affecting Motivation}

\subsubsection{Motivation and Needs}

Need is a concept related to the deficiency of something necessary or desired or perceiving it as a deficiency. While needs can sometimes be simple such as hunger and thirst, they can sometimes be complicated and abstract such as the need for harmony and understanding.

Needs rarely come to the point of perfect or total satisfaction; however, the feeling of deprivation is always possible. Therefore, people concentrate on a goal to meet their needs. We can also define it as using one's potential as best as possible and making an effort to be whatever he/she wants to be. Maslow's hierarchy of needs has been extremely effective in providing educators with students' motivation. Another factor that affects motivation is the need for success. It is also possible to define a certain task or behaviour as a desire to do as best as possible. People with high expectations of success value the work they do and strive to bring out the best from everyone. Individuals' needs for success hide their expectation of success and fear of failure (Çelik, 2011).

\subsubsection{Motivation and Goals}

Setting goals and self-evaluation in achieving this goal is an important source of motivation. A negative contradiction between the goal and the performance set to achieve this goal creates a negative force in the individual for change. As people struggle in line with their goals, they become aware of their development and maintain their motivation.

People who set performance goals focus on demonstrating high-level success and avoiding failure. Here, the target is not about learning the subject, but rather about the results to be achieved, such as high marks or awards. On the other hand, people who have learning goals focus on learning the specified subject in a versatile way. People who are willing to learn do not worry about achieving anything or being compared to other people; their main purpose is to have a perfect grasp of the desired subject (Sawatsky et al., 2020).

\subsubsection{Motivation and Arousal}

The general arousal state associated with motivation is the psychological and physical interaction specific to the environment. While physically aroused factors such as heart palpitations, tremors, and increase in blood pressure are observed, psychologically, it appears as anxiety. Low or high level of arousal (anxiety) is not a healthy behaviour in terms of learning. While a high level of arousal and excitement negatively affect the motivation to learn, not wanting to go to school or indifference appears as a low level of arousal state (Bradley, Codispoti, Cuthbert, \& Lang, 2001).

\subsubsection{Motivation and Beliefs}

The last individual factor that affects people's motivation is individuals' beliefs. While various research results with the loading theory indicated that the capacities were both stable and uncontrollable, some argued that the capacities would be developed vigorously. On the other hand, there are variations in developmental beliefs that come with ability. Young people are optimistic about what they can achieve, and their expectations for success are just as high. People of this age believe that people of high capacity make a great deal of effort and this effort transforms them into a talented person (Hasirc1, 2000).

\subsection{Athlete and Motivation}

Sport has always existed in human life. The interaction of sports, which is affected by every development in the world, with different disciplines is inevitable (Murathan \& Murathan, 2019). Sports is the process of practicing the acquired behaviors by providing physical activity, basic motor skills, mental and psycho-social behaviors in individuals and their development (Murathan \& Orak, 2017). At the same time, sports includes the individual's activities mainly to increase her/his physical or mental performance (Yazıcı \& Özdemir, 2020). The place and importance of sports cannot be denied in being a healthy society, integrating with the universe, advancing, being 
a society with social justice and a bright environment (Yazıc1, 2014). Exercising also has beneficial effects on individuals' social and personality character development (Danac1, 2008; Yazıc1, Ogan, Öztürk, \& Özdemir, 2019). The competitive environment in sports and the fact that winning is always at the forefront should improve the physical and psychological strength of athletes (Yazıc1, Özdemir, Bedir, \& Öztürk, 2018).

Sport supplies an environment in which persons need to motivate themselves intensely to succeed in their aims. As a result, athletes experience both negative and positive emotions in their sport competitions when facing rivalry tension and stress (Sukys, Tilindiene, Cesnaitiene, \& Kreivyte, 2019). Motives that encourage athletes to continue to participate in sports maintain their importance in contemporary sports (Cid et al., 2019). Athletes' motivations can be intrinsic or extrinsic, as patterns can be premise or consequence. Also, the motivation process is dynamic, and it may vary, depending on the changing sports experience (Kilpatrick, Hebert, \& Bartholomew, 2005) or athlete's gender (Sterling, Lindwall, \& Hassmen, 2015). Athlete motivation is one of the most important factors in athletes' performances. It is very important for the trainers to have sufficient knowledge about athlete motivation and implement the motivation methods they will make in the training and games they put forward. Thus, understanding and managing athletes' motivation is often a complex process (Schneider \& Baker, 2006). The link between athletes' motivation and success is very important. It is possible to see poor performance in a situation with a low level of motivation. Each person tends to direct himself/herself towards situations that give him/her peace and happiness and avoid situations that disturb and make him/her unhappy. The approach and avoidance impulses in humans are present in motivational structures. Whichever trend prevails in the situation at that moment, motives emerge towards that direction (İkizler \& Karagözoğlu, 1997). For a good performance to be demonstrated, it is necessary to be physiologically and physically strong, as well as psychologically healthy and strong. Many theorists have put forward various ideas about the participation of athletes in long-term physical activities and to ensure their continuity. One of the examples of these theories is success motivation theory. This theory struggles to explain the reasons why people participate in physical activities, the reasons for overcoming an activity that is stated as power, thus the intensity of force they spend, and the reasons why they can continue this for a long time (Tiryaki, 2000).

\section{Method}

\subsection{Research Model}

In this study, "Scanning and Description Model" has been used. It is a research approach that does not fully describe a past or present situation, but aims to define it. In this model, there is no effort to change and influence whatever is the subject of research. What you want to know is very clear. The goal is to be able to observe and identify that phenomenon correctly. Observing without attempting to change is the main goal (Karasar, 1984).

\subsection{Population and Sample}

The study population is 160 students from the Department of Physical Education and Sports Teaching in Kazım Karabekir Faculty of Education at Atatürk University in the 2019-2020 academic year. The study sample is 99 students out of 160 students chosen by random sampling method.

\subsection{Data Collection}

A form consisting of two parts has been used as a data collection tool in the study. In the first part of the data collection tool, there is a personal information form consisting of students' age, gender and sports branch information. In the second part, there is a scale developed by Gill, Gross and Huddleston (1983) including 30 items and 8 sub-dimensions (Skill Development, Team Membership/Spirit, Fun, Friends, Achievement/Status, Physical Fitness Movement/Activeness and Competition). Individuals' reasons for participation in sports are evaluated on a 3-scale such as "Very Important (1)", "Less Important (2)" and "Not Important (3)". Low scores from the scale show that the motivation to participate in sports is important, while high scores indicate that it is not important. The reliability and validity studies of the original scale were conducted by Gill et al. and Cronbach's alpha coefficient was determined to be between .78 (Achievement/Status) and .30 (Friend) for the sub-dimensions. The reliability of PMQ with the test-retest method was found .68. The inventory was translated into Turkish by Çelebi in 1993 and the reliability coefficient obtained from the whole scale was found to be .91 . The validity and reliability study of the inventory was conducted by Oyar, Aşçı, Çelebi, and Mülazımoğlu (2001) in the summer sports school and 8 sub-dimensions were found. Cronbach's alpha internal consistency coefficient for the sub-dimensions was found between .61 (Skill Development) and .78 (Achievement/Status). Internal consistency obtained from the total scale was found as .86. In the study, Cronbach's alpha internal consistency coefficient for PMQ sub-dimensions was found between .45 (Skill Development) and .60 (Team Membership/Spirit) and the internal consistency obtained from the total scale of 42 was found as .86. According to the results, it can be claimed that PMQ is considered as a reliable tool in this study. 


\subsection{Analysis of Data}

After obtaining the necessary permissions for the research, the data collection tool was filled out as Google Form by 99 students from Atatürk University Kazım Karabekir Faculty of Education Department of Physical Education and Sports Teaching. The scales filled in were checked and transferred to the "SPSS 22.0 for Windows (Statistical Package for Social Sciences)" statistics program, and frequency, percentage and arithmetic averages were calculated. Firstly, descriptive statistics of the data were carried out. Normal distribution criteria were checked by using Kolmogorov-Smirnov and Shapiro-Wilk tests. It was determined that the data did not show a normal distribution. Non-parametric tests were used in the statistical analysis performed at the next stage. While comparisons of gender and sports type were performed with the Mann Whitney-U test, the Kruskal Wallis test was used for the age variable. In the significance of the difference between independent groups, an error level of $\alpha=0.05$ was taken into account.

\section{Findings}

Table 1. Findings of the athletes participating in the study regarding the demographic features

\begin{tabular}{lcc}
\hline & $\mathrm{N}$ & $\%$ \\
\hline Gender & & \\
Female & 35 & 35.4 \\
Male & 64 & 64.6 \\
Age & & \\
18-22 years old & 37 & 37.4 \\
22-26 years old & 56 & 56.5 \\
26 years old and above & 6 & 6.1 \\
Branch of Sports & & \\
Team Sports & 54 & 54.5 \\
Individual Sports & 45 & 45.5 \\
\hline
\end{tabular}

When the gender status of the participants was analysed, 35.4\% $(\mathrm{n}=35)$ were female and $64.6 \%(\mathrm{n}=64)$ were male athletes. $37.4 \%$ of the participants $(\mathrm{n}=37)$ are between $18-22$ years old, $56.5 \%(\mathrm{n}=56)$ are between $22-26$ years old and $6.1 \%(\mathrm{n}=6)$ are 26 years old and above. While $45.5 \%(\mathrm{n}=45)$ of the participants do individual sports, $54.5 \%$ (54) of them do team sports.

Table 2. Distribution of points obtained from participation motivation questionnaire

\begin{tabular}{lcc}
\hline Sub-dimensions & $\bar{X}$ & SS \\
\hline Achievement/Status & 1.272 & .264 \\
Team Membership/Spirit & 1.330 & .406 \\
Physical Fitness & 1.278 & .355 \\
Fun & 1.229 & .328 \\
Friends & 1.356 & .452 \\
Competition & 1.208 & .331 \\
Movement/Activeness & 1.198 & .330 \\
Skill Development & 1.197 & .326 \\
TOTAL & 58.60 & 14.370 \\
\hline
\end{tabular}

In Table 2, the arithmetic mean and standard deviation values of the scores obtained by the participants from the sub-dimensions of the Participation Motivation Questionnaire are presented. As a result of the analysis, it has been understood that the most important reason that led students to sports was "skill development", and the least important reason was "friends". On the other hand, the scores obtained by the participants from the sub-dimensions of the scale show that the students consider all of their incentives to participate in sports as "very important". 
Table 3. Descriptive statistics of the participation motivation questionnaire

\begin{tabular}{cccccc}
\hline & $\mathrm{n}$ & $\bar{X}$ & Ss & Min & Max \\
\hline Participation Motivation Questionnaire & 99 & 36.798 & 7.641 & 29 & 72 \\
\hline
\end{tabular}

Average values of the factors of sports participation scale are given in the table. It was determined that the average of the listening skill scale was $36.798 \pm 7.641$ and the low score obtained was 29 and the highest score was 72 .

Table 4. Mann Whitney U-test results of participation motivation by gender

\begin{tabular}{|c|c|c|c|c|c|c|c|}
\hline Sub-dimensions & Group & $\mathrm{N}$ & Mean Rank & Rank Sum & $\mathrm{u}$ & $\mathrm{z}$ & $\mathrm{p}$ \\
\hline \multirow{2}{*}{ Achievement/Status } & Female & 35 & 49.59 & 1735.50 & \multirow{2}{*}{1105.500} & \multirow{2}{*}{-.110} & \multirow{2}{*}{.912} \\
\hline & Male & 64 & 50.23 & 3214.50 & & & \\
\hline \multirow{2}{*}{ Team Membership/Spirit } & Female & 35 & 51.13 & 1789.50 & \multirow{2}{*}{1080.500} & \multirow{2}{*}{-.304} & \multirow{2}{*}{.761} \\
\hline & Male & 64 & 49.38 & 3160.50 & & & \\
\hline \multirow{2}{*}{ Physical Fitness } & Female & 35 & 49.26 & 1724.00 & \multirow{2}{*}{1094.000} & \multirow{2}{*}{-.200} & \multirow{2}{*}{.84} \\
\hline & Male & 64 & 50.41 & 3226.00 & & & \\
\hline \multirow{2}{*}{ Fun } & Female & 35 & 49.03 & 1716.00 & \multirow{2}{*}{1086.000} & \multirow{2}{*}{-.269} & \multirow{2}{*}{.788} \\
\hline & Male & 64 & 50.53 & 3234.00 & & & \\
\hline \multirow{2}{*}{ Friends } & Female & 35 & 51.14 & 1790.00 & \multirow{2}{*}{1080.000} & \multirow{2}{*}{-.313} & \multirow{2}{*}{.75} \\
\hline & Male & 64 & 49.38 & 3160.00 & & & \\
\hline \multirow{2}{*}{ Competition } & Female & 35 & 50.06 & 1752.00 & \multirow{2}{*}{1118.000} & \multirow{2}{*}{-.017} & \multirow{2}{*}{.98} \\
\hline & Male & 64 & 49.97 & 3198.00 & & & \\
\hline \multirow{2}{*}{ Movement/Activeness } & Female & 35 & 46.13 & 1614.50 & \multirow{2}{*}{984.500} & \multirow{2}{*}{-1.102} & \multirow{2}{*}{.271} \\
\hline & Male & 64 & 52.12 & 3335.50 & & & \\
\hline \multirow{2}{*}{ Skill Development } & Female & 35 & 53.49 & 1614.50 & \multirow{2}{*}{998.000} & \multirow{2}{*}{-1.033} & \multirow{2}{*}{.302} \\
\hline & Male & 64 & 48.09 & 3335.50 & & & \\
\hline
\end{tabular}

$* \mathrm{p} \leq .05$.

In Table 4, Mann Whitney U-Test results of students' participation motivation are presented according to gender. Considering Table 4, no significant difference was observed when the Mann Whitney U-Test results were examined.

Table 5. Mann Whitney U-test results of participation motivation by sport type

\begin{tabular}{|c|c|c|c|c|c|c|c|}
\hline Sub-dimensions & Group & $\mathrm{N}$ & Mean Rank & Rank Sum & $\mathrm{u}$ & $\mathrm{z}$ & $\mathrm{p}$ \\
\hline \multirow{2}{*}{ Achievement/Status } & Team Sports & 54 & 49.78 & 2688.00 & \multirow{2}{*}{1203.000} & \multirow{2}{*}{-.087} & \multirow{2}{*}{.930} \\
\hline & Individual Sports & 45 & 50.27 & 2262.00 & & & \\
\hline \multirow{2}{*}{ Team Membership/Spirit } & Team Sports & 54 & 46.68 & 2520.50 & \multirow{2}{*}{1035.500} & \multirow{2}{*}{-1.324} & \multirow{2}{*}{.185} \\
\hline & Individual Sports & 45 & 53.99 & 2429.50 & & & \\
\hline \multirow{2}{*}{ Physical Fitness } & Team Sports & 54 & 49.72 & 2685.00 & \multirow{2}{*}{1200.000} & \multirow{2}{*}{-.111} & \multirow{2}{*}{.912} \\
\hline & Individual Sports & 45 & 50.33 & 2265.00 & & & \\
\hline \multirow{2}{*}{ Fun } & Team Sports & 54 & 48.03 & 2593.50 & \multirow{2}{*}{1108.500} & \multirow{2}{*}{-.810} & \multirow{2}{*}{.418} \\
\hline & Individual Sports & 45 & 52.37 & 2356.50 & & & \\
\hline \multirow{2}{*}{ Friends } & Team Sports & 54 & 51.50 & 2781.00 & \multirow{2}{*}{1134.000} & \multirow{2}{*}{-.608} & \multirow{2}{*}{.543} \\
\hline & Individual Sports & 45 & 48.20 & 2169.00 & & & \\
\hline \multirow{2}{*}{ Competition } & Team Sports & 54 & 49.02 & 2647.00 & \multirow{2}{*}{1162.000} & \multirow{2}{*}{-.429} & \multirow{2}{*}{.668} \\
\hline & Individual Sports & 45 & 51.18 & 2303.00 & & & \\
\hline \multirow{2}{*}{ Movement/Activeness } & Team Sports & 54 & 47.06 & 2541.50 & \multirow{2}{*}{1056.500} & \multirow{2}{*}{-1.237} & \multirow{2}{*}{.216} \\
\hline & Individual Sports & 45 & 53.52 & 2408.50 & & & \\
\hline \multirow{2}{*}{ Skill Development } & Team Sports & 54 & 50.38 & 2720.50 & \multirow{2}{*}{1194.500} & \multirow{2}{*}{-1.167} & \multirow{2}{*}{.888} \\
\hline & Individual Sports & 45 & 49.54 & 2229.50 & & & \\
\hline
\end{tabular}


In Table 5, Mann Whitney U-Test results are presented according to participation motivation of the students. When Table 5 is evaluated, no significant difference was observed when the Mann Whitney U-Test results were examined.

Table 6. Kruskal Wallis test results of participation motivation according to age

\begin{tabular}{|c|c|c|c|c|c|c|}
\hline Sub-dimensions & Groups & $\mathrm{N}$ & Mean Rank & $X^{2}$ & sd & $\mathrm{p}$ \\
\hline \multirow{3}{*}{ Achievement/Status } & 18-22 years old & 37 & 46.49 & \multirow{3}{*}{1.406} & \multirow{3}{*}{3} & \multirow{3}{*}{.407} \\
\hline & $22-26$ years old & 56 & 51.04 & & & \\
\hline & 2626 years old and above & 6 & 62.00 & & & \\
\hline \multirow{3}{*}{ Team Membership/Spirit } & 18-22 years old & 37 & 47.18 & \multirow{3}{*}{.730} & \multirow{3}{*}{3} & \multirow{3}{*}{.694} \\
\hline & 22-26 years old & 56 & 52.04 & & & \\
\hline & 2626 years old and above & 6 & 48.33 & & & \\
\hline \multirow{3}{*}{ Physical Fitness } & 18-22 years old & 37 & 46.23 & \multirow{3}{*}{3.338} & \multirow{3}{*}{3} & \multirow{3}{*}{.188} \\
\hline & $22-26$ years old & 56 & 50.55 & & & \\
\hline & 2626 years old and above & 6 & 68.08 & & & \\
\hline \multirow{3}{*}{ Fun } & 18-22 years old & 37 & 52.20 & \multirow{3}{*}{4.304} & \multirow{3}{*}{3} & \multirow{3}{*}{.116} \\
\hline & $22-26$ years old & 56 & 46.51 & & & \\
\hline & 2626 years old and above & 6 & 69.00 & & & \\
\hline \multirow{3}{*}{ Friends } & $18-22$ years old & 37 & 49.30 & \multirow{3}{*}{.040} & \multirow{3}{*}{3} & \multirow{3}{*}{.980} \\
\hline & 22-26 years old & 56 & 50.43 & & & \\
\hline & 2626 years old and above & 6 & 50.33 & & & \\
\hline \multirow{3}{*}{ Competition } & $18-22$ years old & 37 & 50.14 & \multirow{3}{*}{1.854} & \multirow{3}{*}{3} & \multirow{3}{*}{.396} \\
\hline & 22-26 years old & 56 & 48.51 & & & \\
\hline & 2626 years old and above & 6 & 63.08 & & & \\
\hline \multirow{3}{*}{ Movement/Activeness } & $18-22$ years old & 37 & 42.69 & \multirow{3}{*}{4.763} & \multirow{3}{*}{3} & \multirow{3}{*}{.042} \\
\hline & 22-26 years old & 56 & 54.69 & & & \\
\hline & 2626 years old and above & 6 & 56.33 & & & \\
\hline \multirow{3}{*}{ Skill Development } & 18-22 years old & 37 & 48.53 & \multirow{3}{*}{.590} & \multirow{3}{*}{3} & \multirow{3}{*}{.745} \\
\hline & $22-26$ years old & 56 & 50.24 & & & \\
\hline & 26 years old and above & 6 & 56.83 & & & \\
\hline
\end{tabular}

$* \mathrm{p} \leq .05$.

Table 6 shows the Kruskal Wallis Test results according to the age variable of students' participation motivation. As a result of the analysis, it was determined that there was a significant difference in the "Movement/Activeness" $\left(\mathrm{X}^{2}=4.763, \mathrm{p}=.042\right)$ sub-dimension of Participation Motivation according to the age variable $(\mathrm{p}<.05)$. No significant difference was found in other sub-dimensions according to the age variable. Mann Whitney U test was conducted to determine the source of the resulting significance. Accordingly, it was determined that the scores of the students between the ages of 18-22 in the Movement/Activeness sub-dimension were significantly higher than the scores of the students between the ages of $22-26(Z=2.120 \mathrm{p}=.034)(\mathrm{p}$ $<0.05)$.

\section{Results and Discussion}

The study consists of $35.4 \%(n=35)$ female and 64.6\% $(n=64)$ male students studying at Atatürk University Kazım Karabekir Faculty of Education Department of Physical Education and Sports Teaching.

According to the results of the Mann Whitney U-Test to determine the gender of the participants and their participation motivation, it was revealed that there was no statistically significant difference between the students' incentive to participate in sports and gender. When similar studies on the subject were considered, it was revealed that Ryckman and Hamel (1993) conducted a study on 123 high school students, and there was no gender difference in participation motivation in that study. However, Başar's (2014) study on analysis of participation motivation of athletes who play underwater hockey in Turkey in order to determine whether sports entertainment points show a significant difference according to gender variables on average; the difference between group means were found statistically significant. It was found the entertainment scores of male athletes higher than the entertainment scores of female athletes. In a study conducted by Aktop and Akkoyun (2011) with 
athletes between the ages of 12 and 14, it was determined that there was a statistically significant difference between the entertainment and physical fitness sub-dimensions of participation motivation, and boys achieved higher values than girls.

According to the results of the Mann Whitney U-Test to determine the sports type of the participants and their participation motivation, it was revealed that there was no statistically significant difference between the sports participation motivation of the students and the type of sports. As a result of the various literature studies conducted on the subject, there is no study that supports us. However, Y1lmaz, Koruç, Kocaekşi, \& Arsan (2010) found significant differences in participation motivation according to sports types in their research examining the reasons for participation in sports. It has been determined that athletes participating in team sports have higher motives in the sub-dimensions of team membership/spirit and activeness than those participating in individual sports. In a study aiming to analyse the participation motivation, perception of success, and self-efficacy of students, the sub-dimensions of "participation motivation of athletes" engaged in team sports and individual sports were analysed, and a significant difference was found in the "team membership/spirit" motive sub-dimension. It has been determined that students in team sports have a higher "team membership/spirit" motive than students in individual sports (Bozkurt, 2014).

According to the results of the Kruskal Wallis Test to determine the participants' motivation to by age, it was determined that there is a significant difference in the sub-dimension of "Movement/Activeness" $\left(\mathrm{X}^{2}=4.763\right.$, $\mathrm{p}=.042)(\mathrm{p}<.05)$. No significant difference was found in other sub-dimensions according to the age variable. Mann Whitney $U$ test was conducted to determine the source of the resulting significance. Accordingly, it was determined that the scores of the students between the ages of 18-22 in the Movement/Activeness sub-dimension were significantly higher than the scores of the students between the ages of $22-26(Z=2.120 \mathrm{p}=.034)$ $(\mathrm{p}<0.05)$.

When similar studies on the subject were reviewed, it was understood that there was no difference due to the age variable in the study on analysing the motivation levels of team sports according to different variables by Kılınç, Ulucan, Kaya, and Türkçapar (2011). However, Altıntaş, Hacıoğlu, Sağtürk, Belman, \& Aş̧̧ı (2010), on the other hand, in their study analysing the relationship between their participation motivation and their perception of success of young football players with an average age of 14, they concluded that the most important participation motivation are skill development and team membership sub-dimension. Similarly, Salguero et al. (2004) found in their study with Spanish swimmers that the most important factor for swimmers with an average age of 14 is the skill development sub-dimension.

It was observed that the most important reason directing students to sports "skill development" and the least important reason was "friends" according to the scores obtained by the participants from the sub-dimensions of Participation Motivation Questionnaire. On the other hand, the scores obtained by the participants from the sub-dimensions of the scale show that students evaluate all of their participation motivation as "very important". Although this situation does not show consistency with other research results, it can be thought that these results will be consistent in itself since the students are inclined to any sports branch for being a student in the Department of Physical Education and Sports Teaching. Furthermore, students are also mentally comfortable.

The study was conducted to determine the most important reasons for Physical Education and Sports Teaching students' orientation to sports and determine whether there is a significant relationship between these reasons according to variables such as age, gender, and type of sport. Totally, 99 students (54 male and 35 female) participated in this research.

When the arithmetic mean and standard deviation values of the scores they obtained from the sub-dimensions of the Participation Motivation Questionnaire were analysed, it was understood that the most important reason that led students to sports was "skill development" and the least important reason was "friends".

When considering the values obtained from the Participation Motivation Questionnaire by Gender, it was observed that there was no statistically significant difference according to the scores obtained by male and female students from the sub-dimensions of the scale.

Considering the values obtained from the Participation Motivation Questionnaire according to sports type, it was understood that there was no statistically significant difference according to the scores of the students who do individual sports and team sports from the sub-dimensions of the scale.

According to the age variable, it was determined that there is a significant difference in the "Movement/Activeness" sub-dimension of Participation Motivation Questionnaire. No significant difference was found in other sub-dimensions according to the age variable. According to the Mann Whitney U test to determine 
the source of the resulting significance, it was determined that there is a significant difference between the scores of the students between the ages of 18-22 in the Movement/Activeness sub-dimension.

\section{References}

Akbaba, S. (2006). Eğitimde motivasyon. Kazım Karabekir Eğitim Fakültesi Dergisi, 13, 343-361.

Aktop, A., \& Akkoyun, H. (2011). Participation motives of primary school athletes. Scientific Report Series Physical Education and Sport, 15(1), 263-266.

Altıntaş, A., Hacıoğlu, O., Sağtürk, B., Belman, C., \& Aşçı, F. H. (2010). Genç futbol oyuncularının spora katılım güdüleri ve başarı algıları arasındaki ilişkinin incelenmesi. Türkiye Klinikleri Spor Bilimleri Dergisi, 2(1), 26-31.

Başar, O. (2014). Türkiye'de sualtı hokeyi oynayan sporcuların spora katılım motivasyonlarının belirlenmesi. Yüksek Lisans Tezi. Sosyal Bilimler Enstitüsü. Bahçeşehir Üniversitesi. İstanbul.

Boiché, J., \& Sarrazin, P. (2007). Motivationautodéterminée, perceptions de conflit et d'instrumentalité et assiduitéenvers la pratiqued'uneactivitéphysique: Uneétudeprospective sur sixmois. Psychologie Française, 52, 417-430. https://doi.org/10.1016/j.psfr.2007.02.002

Bozkurt, Ş. (2014). Okul sporlarına katılan ögrencilerin katılım motivasyonu, başarı algısı ve öz yeterliklerinin incelenmesi. Yüksek Lisans Tezi. Akdeniz Üniversitesi Sağlık Bilimleri Enstitüsü. Antalya.

Bradley, M. M., Codispoti, M., Cuthbert, B. N., \& Lang, P. J. (2001). Emotion and motivation I: defensive and appetitive reactions in picture processing. Emotion (Washington, D.C.), 1(3), 276-298. https://doi.org/10.1037/1528-3542.1.3.276

Breva, A., \& Galindo, M. P. (2020). Types of motivation and eudemonic well-being as predictors of academic outcomes in first-year students: A self-determination theory approach. PsyCh journal, 9(5), 609-628. https://doi.org/10.1002/pchj.361

Canıtezer, A. (2014). 8. sinı öğrencilerinin yazma motivasyonu ile yazılı anlatım beceri düzeyleri üzerine bir araştırma (Yayınlanmamış Doktora Tezi). Necmettin Erbakan Üniversitesi, Eğitim Bilimleri Enstitüsü, Türkçe Eğitim Dalı, Konya.

Çelik, A. (2011). Spor kulüp yöneticilerinin çatışmay yönetme stratejilerinin mükemmeliyetçilik özellikleri ve motivasyon düzeyleriyle iliş̧kisi (Yayınlanmamış doktora tezi). Gazi Üniversitesi, Ankara.

Cid, L., Pires, A., Borrego, C., Duarte-Mendes, P., Teixeira, D. S., Moutão, J. M., \& Monteiro, D. (2019). Motivational determinants of physical education grades and the intention to practice sport in the future. PloS one, 14(5), e0217218. https://doi.org/0.1371/journal.pone.0217218

Danacı M. (2008). Adana ilinde farkl tipteki liselerde öğrenim gören adolesan dönemi sedanter ve spor yapan erkek ögrrencilerin spora yaklaşımı, fiziksel yapıları ve fizyomotorik özelliklerinin saptanması. Yüksek lisans tezi, sağlık bilimleri enstitüsü. Çukurova üniversitesi. Adana.

Gill, D. L., Gross, J. B., \& Huddleston, S. (1983). Participation motivation in youth sport. International Journal of Sport Psychology, 14, 1-14.

Hasırc1, S. (2000). Sporda denetim odağı. Ankara: Bağırgan Yayınevi.

İkizler, H. C., \& Karagözoğlu, C. (1997). Sporda başarının psikolojisi. İstanbul: Alfa Yayınları.

Ingledew, D. K., Markland, D., \& Sheppard, K. E. (2004). Personality and self-determination of exercise

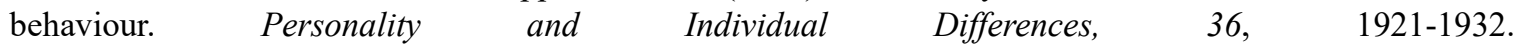
https://doi.org/10.1016/j.paid.2003.08.021

Kaya, M. (2017). Arapça öğreniminde motivasyonun rolü: Atatürk üniversitesi ilâhiyat fakültesi örneği. Atatürk Üniversitesi Sosyal Bilimler Enstitüsü Dergisi, 21(3), 988.

Kılınç, M., Ulucan, H., Kaya, K., \& Türkçapar, Ü. (2011). Takım sporu yapanların motivasyon düzeylerinin farklı değişkenlere göre incelenmesi, Abant İzzet Baysal Üniversitesi. Eğitim Fakültesi Dergisi, 11(2).

Kilpatrick, M., Hebert, E., \& Bartholomew, J. (2005). College students' motivation for physical activity: Differentiating men's and women's motives for sport participation and exercise. Journal of American College Health, 54, 87-94. https://doi.org/10.3200/JACH.54.2.87-94

Knittle, K., Nurmi, J., Crutzen, R., Hankonen, N., Beattie, M., \& Dombrowski, S. U. (2018). How can interventions increase motivation for physical activity? A systematic review and meta-analysis. Health 
psychology review, 12(3), 211-230. https://doi.org/10.1080/17437199.2018.1435299

Koçel, T. (2005). İsletme yöneticiliği, yönetim ve organizasyonlarda davranış klasik modern-çağdaş ve güncel yaklaşımlar, 10. Bası. Arıkan Basım Yayım Dağıtım Ltd. Şti, İstanbul.

Moreno, R. (2009). Educational psychology. John Wiley \& Sons Inc., USA.

Murathan, T., \& Murathan, F. (2019). Spor sektöründe blok zinciri uygulamaları. Gaziantep Üniversitesi Spor Bilimleri Dergisi, 4(1), 64-74. https://doi.org/10.31680/gaunjss.484614

Murathan, T., \& Orak, G. (2017). Ardahan'da çocuk oyunları ve spor kültürü. Spor Yayınevi ve Kitabevi, Isbn: 978-9944-379-79-3. Ankara.

Onaran, O. (1981). Çalışma Yaşamında Güdülenme Kuramları. Ankara Üniversitesi Siyasal Bilgiler Fakültesi Yayınları, Ankara.

Osabiya, B. J. (2015). The effect of employees motivation on organizational performance. Journal of public administration and policy research, 7(4), 62-75. https://doi.org/10.5897/JPAPR2014.0300

Oyar, Z. B., Aşçı, H. F., Çelebi, M., \& Mülazımoğlu, Ö. (2001). Spora katılım güdüsü ölçeği’nin geçerlik ve güvenirlik çalışması. H.Ü. Spor Bilimleri Dergisi, 12(2), 21-23.

Park, S. H., Lim, B. S., \& Lim, S. T. (2020). The Effects of Self-Talk on Shooting Athletes' Motivation. Journal of sports science \& medicine, 19(3), 517-521.

Ryckman, R. M., \& Hamel, J. J. (1993). Perceived physical ability differences in the sport participation motives of young athletes. International Journal of Sport Psychology, 24(3), 270-283.

Salguero, A., Gonzalez-Boto, R., Tuero, C., \& Marquez, S. (2004). Relationship between perceived physicality and sport participation motives in young competitive winners. Journal of Sports Medicine and Physical Fitness, 44(3), 294-299.

Sawatsky, A. P., Halvorsen, A. J., Daniels, P. R., Bonnes, S. L., Issa, M., Ratelle, J. T., Stephenson, C. R., \& Beckman, T. J. (2020). Characteristics and quality of rotation-specific resident learning goals: A prospective study. Medical education online, 25(1), 1714198. https://doi.org/10.1080/10872981.2020.1714198

Schneider, R. C, \& Baker, R. E. (2006). Obtaining maximum effort and results from your athletes through motivation strategies. Strategies, 19(6), 27-31. https://doi.org/10.1080/08924562.2006.10591224

Stenling, A., Lindwall, M., \& Hassmen, P. (2015). Changes in perceived autonomy sup- port, need satisfaction, motivation, and well-being in young elite athletes. Sport, Exercise, and Performance Psychology, 4, 50. https://doi.org/10.1037/spy0000027

Sukys, S., Tilindienè, I., Cesnaitiene, V. J., \& Kreivyte, R. (2019). Does Emotional Intelligence Predict Athletes' Motivation to Participate in Sports? Perceptual and motor skills, 126(2), 305-322. https://doi.org/10.1177/0031512518825201

Tiryaki, Ş. (2000). Spor psikolojisi kavramlar, kuramlar ve uygulama (1. bask1). Eylül Yayınc1lık. Ankara.

Yazıcı, A. G. (2014). Toplumsal Dinamizm ve spor. Uluslararası Türkçe Edebiyat Kültür Eğitim Dergisi, 3(1), 403. https://doi.org/10.7884/teke.280

Yazıc1, A. G., \& Özdemir, K. (2020). The Importance of sports education towards social alienation in the process of transition from agricultural society to industrial society (Theory and research in sport sciences, Editor, Özgür Karataş, 1st ed.). Gece Publishing. Ankara.

Yazıc1, A. G., Ogan, M., Öztürk, M. E. \& Özdemir, K. (2019). Student attitudes towards basketball. Journal of Physical Education Research, 6(1), 42-48.

Yazıcı, A. G., Özdemir, K., Bedir, D. \& Öztürk, M. E. (2018). Sürekli sportif güven, yarışmasal durumluk kaygı ve imgelenme arasındaki ilişkinin incelenmesi. IV. Uluslararası Mesleki ve Teknik Bilimler Kongresi, 7-09 December 2018, 1745-1755. Erzurum.

Yılmaz, V., Koruç, Z., Kocaekşi, S., \& Arsan, N. (2010). Çocukların spora katılım nedenleri. 11.Uluslararası Spor Bilimleri Kongresi.10-12 Ekim, Antalya. 


\section{Copyrights}

Copyright for this article is retained by the author(s), with first publication rights granted to the journal.

This is an open-access article distributed under the terms and conditions of the Creative Commons Attribution license (http://creativecommons.org/licenses/by/4.0/). 